\author{
Оксана СОЛОВЙОВА, \\ orcid.org/0000-0002-3289-9140 \\ аспірант кафедри образотворчого мистеитвва, \\ музикознавства та культурології \\ Сумського державного педагогічного університету \\ імені А. С. Макаренка \\ (Суми, Украӥна) soloviov_art@ukr.net
}

\title{
ЖАНР КЛАВІРНОГО КОНЦЕРТУ В ТВОРЧОСТІ СИНІВ БАХА
}

Стаття присвячена аналізу клавірних концертів синів Баха - Вільгельма Фрідемана, Карла Філіппа Емануеля, Йоганна Крістофа Фрідріха та Йоганна Крістіана. Досліджується тип композиції концертів, стилістика тематизму та принциии його розвитку, особливості співвідношення солістів та ансамблевих груп у фактуроутворенні.

Кристалізація сонатної форми в концертній творчості синів Баха має ичікаві тендениії: у Карла Філіппа Емануеля чітко прослідковується еволючія від старовинних форм (дво-, тричастинних, сонатних) до класичної сонатної та рондо; у Вільгельма Фрідемана усталені на той час форми мають дещяо вільне трактування, хоча композитор тяжіє до традииійних старовинних; Йоганн Крістіан є яскравим представником музичного класицизму, форми його концертів також презентують класичні композиціі; Йоганн Крістоф Фрідріх (з огляду на ті творів, які дійили до нас) будує прогресивну на той період форму, розгорнуту за обсягом, а його концерти можна порівняти з концертами В. А. Моцарта.

Також характеризується історичний контекст, який свідчить про різноманітність клавішного інструментарію, особливості співіснування інструментів щиикової та ударної механіки в композиторській і виконавській практиках XVIII cm. Різноманітність інструментарію надавала неабиякі можливості для кониертних форм, у яких поєднувалися різні інструменти, а саме явище концертності збагатилося інструментальною багатоваріантністю.

Виявляються причини, за яких сини Баха віддавали перевагу тому чи іншому інструменту, які залежали від професійної кар'єри композиторів. Якщо В. Ф. Бах віртуозно грав та імпровізував на клавесині та органі, то $i$ перевагу в свойх концертних творах віддавав клавесину. К. Ф. Е. Бах служив придворним композитором, любив експериментувати з інструментами, а його концерти мають як сольний клавесин, так $і$ піанофорте. Й. К. Бах будував кар'єру в Англії, де популярним на той час було нове фортепіано, якому композитор і віддавав перевагу. Й. К. Ф. Бах як один із молодших братів тяжів до піанофорте.

Ключові слова: концерт для клавіру, концертна форма, сини Баха, класицизм, бароко, клавішні інструменти XVIII cm.

Oksana SOLOVIOVA, orcid.org/0000-0002-3289-9140 Graduate Student at the Department of Fine Arts, Musicology and Cultural Studies Sumy State Pedagogical University named after A. S. Makarenko (Sumy,Ukraine) soloviov_art@ukr.net

\section{THE GENRE OF CLAVIRE CONCERT IN THE MUSIC OF BACH'S SONS}

The article is devoted to the analysis of piano concertos by the Bach's sons - Wilhelm Friedemann, Karl Philipp Emanuel, Johann Christoph Friedrich and Johann Christian. Five sons became musicians, four of whom became famous composers. The most influential was the composer's second son, Carl Philipp Emanuel, also known as the Berlin (or Hamburg) Bach.

For thirty years he dedicated his service in the court cappella of Frederick the Great, created a large number music of various genres of choral, vocal and instrumental works, is one of the founders of the style of sentimentalism and he is a representative of early classicism. Wilhelm Friedemann masterfully played the organ, whose professional career was developed in Dresden and Halle (he is called the Gallic Bach). During his life he gained a reputation as the most respected and educated musician, but had the most difficult fate among the brothers of composers. Johann Christoph Friedrich is called Bückenburg's Bach. He preserved the musical traditions of the Bach's family and wrote a large number of different works by genre.

The creative path of his youngest son Johann Christian was like G. F. Handel. He also studied and began his career in Italy, and later received an invitation to England. The type of the concert composition, stylistics of themism and principles 
of its development, peculiarities of the ratio of soloists and ensemble groups in the texture formation are researched. The historical context characterized, which indicates the diversity of keyboard instruments, as well as the peculiarities of the coexistence of instruments of plucked and hammer mechanics in the composition and performance practices of the XVIII century. Instrumental genres of that time significantly expanded and improved due to the popularity of concert and salon music. Instruments with hammer mechanics were popular, although not all composers of the Baroque era were inclined to use them in their own music. This was due to the popularity of musical rhetoric, the harpsichord met such tasks, and the Hammerklavier and Pianoforte had other properties. The variety of designs of keyboard instruments with plucked mechanics allowed composers to diversify musical works, to decorate them with different shades of sound.

$B$. Christoph at the end of the XVII century designed an instrument with an alternative method of sound production, he solved the fundamental problem of the design of the harpsichord and clavichord: he adapted a hammer that struck the string and returned to its original position. The strings of the instrument Gravecembalo col piano e forte, which retained the abbreviated name pianoforte, were thinner than the strings of a modern piano. The reasons why the sons of Bach preferred one or another instrument are revealed. The clavier works of the Bach sons are diverse, they used the existing capabilities of modern instruments. Despite the fact that each of them preferred a certain instrument, also wrote for other keyboard instruments. A different fate (including creative) befell everyone, but each of them wrote works that influenced the further development of European musical art.

Key words: concerto for piano, form of concert, Bach's sons, classicism, baroque, clavier instruments of the XVIII century.

Постановка проблеми. Творчість синів Й. С. Баха, які продовжили ремесло свого батька, припала на середину та другу половину XVIII ст. - період, який пов'язаний із завершенням епохи бароко, зародженням, розвитком і розквітом класицизму. П'ятеро синів стали музикантами, четверо з яких - відомими композиторами. Усіх спіткала різна доля (в тому числі творча), але кожен із них залишив в тій чи іншій мірі творчий спадок і вплинув на подальший розвиток європейського музичного мистецтва.

Троє старших синів були народжені в шлюбі 3 Марією Барбарою у Веймарі, двоє молодших (включаючи наймолодшого) були дітьми Йоганна Себастьяна та Анни Магдалени. Всі вони навчалися музиці у батька з раннього дитинства, тому своєю майстерністю завдячують своєму походженню. Проте життєві шляхи синів Баха мають цікаву та розгалужену географію, з чого витікають особливості творчості кожного з них, в тому числі сюди відносяться уподобання тим чи іншим музичним інструментам (особливо клавішним).

Аналіз досліджень. Нині клавішний інструментарій активно досліджується, практика виконавства на них дає широке поле для різних теорій. Найбільший інтерес викликають роботи виконавців-дослідників (Любімов, 2020), зв'язок із філософською думкою (Остер, Биканова, 2018), дослідження творчості синів Баха (Захваткин, 2007; Ткаченко, 2010), історичний огляд клавірної музики епохи бароко та раннього класицизму (Друскін, 2007; Медведик, 2017).

Мета статті полягає в аналізі концертів для клавіру (щипкової та ударної механіки) синів Й. С. Баха для виявлення тенденцій розвитку жанру в перехідний період європейської музики від бароко до класицизму. Матеріалом дослі- дження слугували нотні видання та аудіозаписи вибраних концертів.

Виклад основного матеріалу. Найбільш впливовим був другий син композитора Карл Філіпn Емануель, якого ще називають Берлінським (або Гамбурзьким) Бахом. 30 років він присвятив службі в придворній капелі Фрідріха Великого, створив велику кількість різних за жанрами хорових, вокальних та інструментальних творів, $\epsilon$ одним із засновників стилю сентименталізму та яскравим представником раннього класицизму. Також вів педагогічну діяльність, маючи авторитет серед впливових музикантів свого часу та своїх видатних учнів, створив методичний посібник для виконавців «Досвід правильного способу гри на клавірі» (Бах, 2005), який вплинув на педагогічні методики М. Клементі та Й. Б. Крамера.

Старший син Вільгельм Фрідеман віртуозно володів грою на органі. Його професійна кар'єра була пов'язана 3 Дрезденом і Галле (через це його називають Галльським Бахом), де він займав посади органіста. Вважається, що улюблений син великого композитора, який спеціально для нього написав I том ДТК, не виправдав надій батька. Через те, що деякі факти його біографії та причини, чому сталися ті чи інші події, залишаються невідомими, складно дійти загального висновку. За життя він отримав репутацію найповажнішого та найосвіченішого музиканта, проте мав найбільш складну долю серед братів-композиторів. Йоганн Готфрід, який намагався будувати кар'єру в Мюльхаузені, не дожив до 24 років.

Діти від другого шлюбу, які мали вікову різницю зі старшими у понад 20 років, жили та творили в розквіт європейського класицизму. Йоганна Kpicmoфa Фрідpixa називають Бюккенбургзьким Бахом. Незважаючи на те, що музичні уподобання 
та стилістика творчості композитора були підкорені художньому смаку графа Шаумбург-Ліппе Вільгельма (орієнтовані на італійську оперу), він зберіг музичні традиції родини Бахів і залишив велику спадщину різних за жанрами творів.

Наймолодший син Йоганн Крістіан у своїй професійній кар'єрі відтворив шлях, схожий на генделевський: через Італію в Англію, через це і став Лондонським Бахом. Він був єдиним із синів Баха автором опер. Музичний англійський класицизм пов'язаний саме $з$ його іменем. Він є одним 3 композиторів (разом із Г. Ф. Генделем і Й. Гайдном), який визначив музичний облік і стилістику англійської музики у XVIII ст.

Інструментальні жанри того часу значно розширилися та вдосконалилися завдяки популярності концертного та салонного музикування. Жанри клавірної музики мали широке різноманіття інструментарію: від інструментів сімейства щипкових клавішних (клавесин, клавікорд, спінет, верджинел, клавіцитерій) та органів до різновидів клавішних інструментів 3 ударною механікою. Останні користувалися популярністю, хоча не всі композитори барокової доби схилялися до їх широкого використання. Це було пов' язано з прийомами гри, які відтворювали певну музичну риторику.

Й. С. Бах користувався риторичними фігурами, які мали конкретний зміст у конкретних творах. Його хорали є своєрідним каталогом усіх відомих на той час мелодично-риторичних фігур, кожна 3 яких у певному контексті несла змістовну функцію. Одне $з$ перших грунтовних досліджень у цьому напрямі здійснив Б. Яворський, який довів, що «всі мотиви, які тоді використовувалися, мали точний смисл, але були звичайного походження, а не навмисного, і використовувалися як спадок народної творчості, закарбованої в григоріанській монодії, а потім у ії переробці в протестантському хоралі» (Носина, 2004: 14).

Композитор володів всіма відомими на той час інструментами, віддаючи перевагу органу та клавесину (з огляду на рід його професійної діяльності протягом кар'єри). Проте на той час клавішні інструменти 3 ударною механікою вже не користувалися популярністю у композитора. «Основна естетична різниця цих інструментів полягала в тому, що фортепіано - інструмент динамічний, а клавесин - риторичний. Й. С. Бах навряд чи міг полюбити фортепіано і дивувався інструменту Зільбермана саме тому, що цей новий інструмент був обмежений щодо відтворення риторики. У творчості ж Баха мистецтво риторики сягає свого піку» (Любимов, Мартынова, Насонов, 2020).
Різноманітність конструкцій клавішних інструментів із щипковою механікою дозволяла композиторам урізноманітнити музичні твори, прикрасити їх різними відтінками звучань. У XVIII ст. інструментарій давав багато можливостей, у ньому панував такий дух змагання, який не потребував перемоги. Музиканти керувалися почуттям curiosité - зацікавленості, допитливості, однак віртуози прагнули різноманітних динамічних можливостей, які міг дати великий інструмент.

«Основним недоліком клавесину було те, що динаміку (гучність або м'якість) кожної ноти не можна було контролювати. Це означало, що композитори не могли належним чином своєю музикою викликати відповідні емоції. Клавікорд був спрямований на усунення цього недоліку. Хоча він і був щипковим, струна могла вібрувати, поки натиснута клавіша. В результаті виконавці могли контролювати гучність інструменту. Клавікорд був більш досконалим і набув неабиякої популярності, проте мав свої недоліки. Його звучання було ніжним, що дозволяло музикантам досягти тонкої виразності, проте за гучністю він поступався клавесину, тому не використовувався у великих залах і з великими ансамблями» (The History of the Piano, 2020).

Б. Крістофі, який був на службі в родини Медичі, наприкінці XVII ст. запропонував інструмент 3 альтернативним способом звуковидобування. Він вирішив фундаментальну проблему конструкції клавесину та клавікорду: пристосував молоток (маленьке кільце зі свинячою шкірою), який ударяв по клавіші та повертався у своє вихідне положення. Звичайно, струни інструменту Gravecembalo col piano e forte, за яким зберігалася скорочена назва pianoforte, були тоншими за струни сучасного фортепіано.

О. Любімов вважає, що «необхідна якість музики XVII і XVIII ст., предромантичної та романтичної музики - це наявність кількох педалей, які керують регістрами, на кшталт клавесину або органу. Це не тільки демпферна педаль - наша права педаль, не тільки una corda - наша ліва педаль. Це педаль-модератор, за допомогою якої між молоточком і струною висувається планка зі смужками тонкої матерії, а звук стає ніби із сурдиною. На пізніх та експериментальних інструментах був присутній арфовий регістр, коли шматочки шкіри підсувалися до струн знизу, у поріжка, і звук походив на арфовий» (Любимов, 2020).

Й. С. Бах знав інструмент Г. Зільбермана, у якого ідея hammer'a отримала подальший розвиток. Майстру покровительствував король Пруссії Фрідріх Великий. «За здатність співати тихо, 
виражати інтимні почуття, на відміну від помпезних клавесинів, Hammerklavier стали називати pianoforte» (Любимов, Мартынова, Насонов, 2020).

Клавірна творчість синів Баха різноманітна, вони користувалися існуючими можливостями сучасного інструментарію. Незважаючи на те, що кожен із них віддавав перевагу певному інструменту, вони писали і для інших клавішних інструментів (як щипкової, так і ударної механіки). Карл Філіпn Емануель Бах віддавав перевагу клавікорду (про що свідчить перший біограф Й. С. Баха Й. Н. Форкель (Форкель, 1987) через кантиленні можливості інструменту, проте гучність звуку була слабша за клавесин, тому, скоріш за все, в концертних формах композитор використовував клавесин і піанофорте. Композитор створив близько 60 концертів (здебільшого для клавіру). Серед них також зустрічаються два подвійних концерти:

- концерт для двох клавесинів та оркестру Фа мажор Wq 46;

- концерт для клавесину, піанофорте та оркестру Мі-бемоль мажор Wq 47;

- концерт десять потрійних концертів;

- концерт для клавіру, двох валторн, струнних і литавр Ре мажор Н 414 (Wq 11);

- концерт для клавіру, струнних, двох валторн i basso continuo Соль мажор Wq 44;

- концерт для клавіру, струнних, двох валторн i basso continuo Мi-бемоль мажор Н 446 (Wq 35);

- концерт для клавіру, струнних, двох валторн i basso continuo Ре мажор H 478 (Wq 45);

- Гамбурзький концерт № 1 для клавіру, струнних, двох валторн i basso continuo Фа мажор Wq 43/1 (H. 471);

- Гамбурзький концерт № 2 для клавіру, струнних, двох валторн i basso continuo Ре мажор Wq 43/2 (H. 472);

- Гамбурзький концерт № 3 для клавіру, струнних, двох валторн і basso continuo Мі-бемоль мажор Wq 43/3 (Н. 473);

- Гамбурзький концерт № 4 для клавіру, струнних, двох валторн i basso continuo до мінор Wq 43/4 (H. 474);

- Гамбурзький концерт № 5 для клавіру, струнних, двох валторн i basso continuo Соль мажор Wq 43/5 (H. 475);

- Гамбурзький концерт № 6 для клавіру, струнних, двох валторн i basso continuo До мажор Wq 43/6.

- Також є один концерт для клавіру соло Ре мажор Wq 112/1 (H. 190).

Концерти, зокрема за участю клавесину та піанофорте, К. Ф. Е. Бах писав протягом життя.
Оскільки композитор увів піанофорте в концертний склад, його концертну спадщину можна назвати експериментальною. Так, концерти для клавіру та струнних Ре мажор Н 416 (Wq 13) та ре мінор Н 425 (Wq 22) передбачають виконання для солюючої флейти (певно, для Фрідріха Великого, який був флейтистом-віртуозом, у якого композитор служив 30 років), можливо, арфи (яка має «холодний» тембр, як і флейта). Близько 40 концертів для клавіру та струнних також передбачають виконання на клавесині або піанофорте.

Одним із найбільш цікавих концертів $€$ концерт для клавесину, піанофорте та оркестру Мі-бемоль мажор Wq 47 (1788), останній концертний опус композитора, в якому він поєднує два протилежних (за принципом звуковидобування) солюючих інструменти - зі щипковою та ударною механікою. I частина - сонатна форма, II - тричастинна, III сонатна. У співвідношенні солістів використовуються різні прийоми: доспівування (продовження мелодичної лінії), дует у консонуючий інтервал (з мотивними варіантами), підголоскова фактура, імітація. В регістровому діапазоні (незважаючи на подібні можливості) мелодичні лінії у піанофорте нижчі за мелодичні лінії клавесину. Якщо в I частині це яскраво не виражено, то в II і III - $€$ закономірністю. Якщо зустрічаються дуетні пасажі або арпеджіо, то у клавесину здебільшого початкові фрази перебувають у висхідному русі, у піанофорте - у низхідному.

Можна сказати, що цей концерт увібрав всі прийоми концертно-дуетного виконавства, які Ф. Е Бах винайшов протягом практики написання концертів для різних інструментів. Твір не тільки узагальнює ці прийоми, а й підкреслює ідею різності у тембрових і кантиленних можливостях інструментів. Переважне використання високого регістру в клавесині, а середнього у піанофорте (особливо у II та III частинах) свідчить про принципово різний підхід композитора до їхньої ролі в ансамблі. Більш кантиленні можливості піанофорте у регістровому вираженні наближені до тембру людського голосу, а яскравий відділений один від одного дзвінкий звук клавесину контрастує йому регістрово.

Концерт для клавесину та струнних ре мінор Wq 23 написаний у 1748 році в Потсдамі. Це період початку творчої зрілості композитора, коли ще відчувається вплив учителів (у тому числі його батька), але вже формується власний почерк і стиль. Тоді ще не були випрацювані класичні форми, музичне мистецтво знаходилося на шляху до появи усталених композиційних форм і принципів. Творчість композиторів середини XVIII ст. 
(в тому числі німецьких) вкладалася в русло тих процесів, результатом яких стало виникнення класичної сонатної та концертної форми (а також сонатно-симфонічного циклу загалом). I частина концерту - старовинна сонатна форма двочастинної структури 3 цікавим тональним планом: ре мінор - соль мінор - ля мінор - До мажор ре мінор, II частина - старовинна двочастинна 3 періодом типу розгортання, III частина - старовинна сонатна форма.

Тип тематизму тяжіє до «вівальдівського» типу, пісенні та танцювальні жанрові джерела використовуються опосередковано, на відміну від «скарлаттіївського», в якому жанрова танцювальна (здебільшого) основа яскраво виявляється в сонатах італійського композитора. У концерті закладена ідея інтонаційного об'єднання: в основних темах переважає широка інтерваліка (більше октави), чіткий пунктирний ритм, акцент на першій долі. Щільна клавесинна фактура підкреслює героїко-патетичний настрій.

Клавірні концерти К. Ф. Е. Баха виконувалися як на клавесині, так і на піанофорте, але вони могли бути замінені іншими інструментами, що доводить гнучкість підходу композиторів тієї доби до виконавських питань. Це вказує на можливість використання інструментального різноманіття. $\mathrm{y}$ формотворенні композитор одним із перших запропонував контрастні головну та побічну партії (Остер, Биканова, 2018: 126). Саме існування музичних творів у різних інструментальних версіях давало поштовх до розвитку, подальших експериментів, композитори із задоволенням робили переклади своїх концертів для різних солістів i ансамблевих/оркестрових складів. Концерти К. Ф. Е. Баха підтверджують тезу про концертність як вікно можливостей для багатьох виконавців.

Каталогізація творчості Вільгельма Фрідемана Баха ускладнюється через те, що багато опусів втрачено, та те, що композитор мав звичку не записувати твори на папері. Він вважався неперевершеним імпровізатором, і деякі композиції виникали прямо на очах у слухачів. Досконало володіючи грою на орані та клавесині, старший син Баха віддавав перевагу клавесину (можливо, піанофорте), створивши для цього інструменту твори різних жанрів: полонези, концерти, сонати, фантазії. Із того музичного спадку, який $є$ відомим, вбачається, що йому притаманна жанрова різноманітність - від інструментальних сольних п’єс до хорових кантат. Зі збережених та ідентифікованих творів відомі два подвійних концерти:

- концерт для двох клавесинів 3 оркестром Мі бемоль мажор;
- концерт для двох клавірів Фа мажор;

- п'ять клавірних концертів:

- концерт для клавесину та струнних ля мінор;

- концерт для клавесину та струнних Ре мажор;

- концерт для клавесину та струнних Фа мажор;

- концерт для клавесину та струнних фа мінор;

- концерт для клавіру (піанофорте) та струнних мі мінор.

Порівнясмо концерти для двох клавірі Фа мажор та концерт для клавесину та струнних ля мінор з точки зору формотворення, типу та якості розвитку тематизму, стилістики та фактурних прийомів.

Концерт для двох клавірів Фа мажор написаний без оркестрового або ансамблевого супроводу, що в першій половині XVIII ст. було традиційною концертною формою. I частина старовинна двочастинна репризна форма, другий розділ якої є періодом типу розгортання, переважає імітаційна та канонічно-імітаційна фактура, сам тематизм вже не барокового складу, тим не менш його розвиток збігається 3 традиційними бароковими прийомами мелодичного розвитку. II частина - двочастинна форма 3 контрастним тематизмом, проте сам його тип та стилістика виходить з барокових безкінечних мелодій, тому під контрастом тут розуміється інше інтонаційне ядро. Проте теми першого та другого розділів розвиваються за принципом проростання, мають багато спільних інтонацій, тому відносно одна одної не контрастують. В повільній частині також зберігається імітаційна та канонічно-імітаційна фактура. III частина - старовинна двочастинна форма, де другий розділ - це період типу розгортання. При збереженні імітаційної фактури, тип розвитку тематизму більш імпровізаційний з вставками фантазійних епізодів.

В концерті для клавесину та струнних ля мінор І частині побудована в старовинній сонатній формі. Відмінністю є наявність двох різних тем в оркестрі та у соліста: оркестрова тема виконує роль основної (головної), тема у соліста імпровізаційна, яка складається 3 пасажів, арпеджіо та інших фігурацій. Проте у співвідношення соліста та оркестру в подальшому розвитку інтонації перетинаються, мотиви проникають 3 одних фактурних пластів в інші, багато секвентно-імітаційного розвитку. II частина має рондальну структуру: основна тема з'являється три рази в основній тональності частини Фа мажор спочатку в оркестрі, потім у соліста. Епізоди імпровізаційного характеру, є розвитком основного тематизму та не контрастують йому. Після третього проведення теми з'являється досить розгорнута кода, 
на що вказує заключний тип тематизму. III частина має елементи рондальної структури з більш вільним трактуванням форми (у порівнянні з формою II частини). Розвиток побудований на основних мотивах, які є основою секвентно-імітаційного руху, та вплітаються в імпровізаційні епізоди.

На прикладі двох концертів бачимо, що В. Ф. Бах активно використовує імпровізаційне начало в тематичному розвитку, функцію якого переважно покладено на солюючі партії. Структури його концертів різноманітні: старовинні двочастинні та сонатні форми, ронадальні та вільні за своєю побудовою. Тип та стилістика тематизму відходить від традиційних барокових мелодій, але зберігається бароковий тип мелодичного розвитку, те ж стосується фактури, яка насичена канонічно-імітаційними та секвентно-імітаційними прийомами. Отже, концертні форми композитора є яскравим прикладом жанру перехідного періоду від бароко до раннього класицизму.

Творчість наймолодшого сина Йоганна Kpicтіана Баха найрізноманітніша за жанрами серед братів. Він $є$ автором опер, реквієму, кантат, мотетів, інструментальних ансамблів для різних складів, близько сорока симфоній, сольних та камерних сонат, більше тридцяти концертів, більшість 3 яких є для клавіру (соло або у супроводі ансамблю або оркестру). 326 клавірних концертів шість мають варіант для арфи, це перші опуси композитора, враховуючи, що він вчився і у свого батька, і у старшого брата Карла Філіппа Емануєля, він ще в ранні роки опанував піанофорте, з цим інструментом пов'язана його подальша професійна кар'єра. Ще в молоді роки переїхавши в Лондон, став одним 3 пропагандистів нового фортепіано.

Один $з$ ранніх опусів концертів для клавіру та струнних - цикл 3 шести концертів ор. 7. Показовим 3 них є концерт № 5 Мі-бемоль мажор. Роки студіювання в Болоньї для композитора мали неабиякий вплив на формування його авторського стилю. Музика італійських композиторів для нього була взірцем. В даному концерті композитор активно використовує альбертієви баси. I частина має класичну сонатну побудову, особливістю тематизму є його діатонічна основа, альтерація виникає переважно лише в модуляціях. Тип мелодики «прозорий», не перевантажений мелодичною фігурацією (в т.ч. хроматичною) затриманнями, оспівуваннями, камбіатами, часто використовуються репетиції, поступовий ритмічно рівномірний рух, оспівування тризвуків. II частина двочастинна, де другий розділ $є$ періодом типу розгортання. III частина має риси рондо, проте епізоди можна назвати варіаційним розвитком основної теми. Форма фіналу композитором трактується досить вільно, незважаючи на те, що він $є$ яскравим представником музичного класицизму, у формотворенні він не тяжіє до стандартів, якими характеризуються музичні твори цього стильового напрямку.

Концерт № 1 До мажор ор. 13 презентує еволюційнийрозвитоктворчостікомпозитора.Навідміну від ранніх творів, засоби виразності в першому концерті, який відкриває цей цикл, відрізняється більш розвинутою мелодикою, сміливими інтонаціями, різноманітністю фактурних прийомів. I частина - сонатна форма 3 яскраво вираженим тематичним контрастом між активною головною та витонченою пісенною побічною партіями. Концерт має в цілому незвичну побудову, він двочастинний, без традиційної середньої повільної частини. II частина також рухлива, має форму рондо. Епізоди контрастують тематично та тонально.

В концертах Й. К. Баха каденції не виписані, виконавець імпровізує, користуючись основним тематизмом. 3 кожним опусом музична мова ускладнюється, зрілі твори переставляють собою кристалізований класичний стиль. Саме концерти композитора сприяли еволюційному розвитку його авторського почерку, в яких він удосконалював не тільки композиторську та власну виконавську майстерність, вони стали прикладом концертних форм для Й. Гайдна та В. А. Моцарта, останній мав особливе ставлення до молодшого Баха, вважав його своїм вчителем та прогресивним композитором сучасності.

Творчу спадщину Йоганна Kpicmoфа Фрідріха Баха спіткала складна доля, велика їі частина була знищена при бомбардування Берліну у 1945 р. Проте твори, які залишились, свідчать про жанрову різноманітність: ораторії, кантати, симфонії, сонати, ансамблі, концерти. Концертні форми залишилися тільки для клавіру:

- концерт для клавіру «Лондонський» № 1 Соль мажор BR-JCFB C 31,

- концерт для клавіру «Лондонський» № 2 Фа мажор BR-JCFB C 32,

- концерт для клавіру «Лондонський» № 3 pe мінор BR-JCFB C 33,

- концерт для клавіру «Лондонський» № 4 Mi-бемоль мажор BR-JCFB C 34,

- концерт для клавіру «Лондонський» № 5 Ci-бемоль мажор BR-JCFB C 35,

- концерт для клавіру «Лондонський» № 6 До мажор BR-JCFB C 36,

- концерт для клавесину Mi мажор BR-JCFB C 37 , 
- концерт для клавесину Фа мажор BR-JCFB C 40,

- концерт для клавесину Pe мажор BR-JCFB C 31,

- концерт для клавесину Ля мажор BR-JCFB C 32,

- великий концерт для клавіру та оркестру Mi-бемоль мажор BR-JCFB C 43,

- концерт для клавіру та альта Мі-бемоль мажор BR-JCFB C 44.

Найбільш відомим концертом $є$ великий концерт для клавіру та оркестру Мі-бемоль мажор BR-JCFB C 43, написаний за три роки до смерті, в якому втілилась майстерність музиканта як композитора та виконавця-віртуоза. Твір є яскравим прикладом класичної концертної форми, великий за обсягом (близько 30 хвилин), він презентує метод класицизму, який стандартизує композицію, тональний розвиток, інструментальні особливості (розподіл оркестрових груп у фактурі).

Висновки. Жанр клавірного концерту в спадщині синів Баха відіграє одну з провідних ролей в еволюції їхньої творчості. Кожен 3 них представляє ранній, середній або пізній період музичного класицизму. Твори старшого сина Вільгельма Фрідемана - це перехідний період від пізнього бароко до раннього класицизму, причому в його музиці цікаво поєднується класичний тип тематизму та барокові принципи його розвитку. Музика Карла Філіппа Емануеля теж має вплив барокових принципів, також в його концертах зустрічаються старовинні форми, але сам $є$ одним 3 засновників стилю сентименталізму, який розвивався в руслі музичного класицизму. Молодші Бахі, Йоганн Крістоф Фрідріх та Йоганн Крістіан $є$ представниками класицизму, а їхня творча спадщина репрезентує провідні класичні форми: сонати, симфонії, концерти. Щодо уподобань, то кожен з синів Баха віддає перевагу різним інструментам, хоча використовує у своїй творчості всі наявні на той час. Карл Філіпп Емануель тяжів до клавікорду, проте в концертних формах використовував клавесин та піанофорте, Вільгельм Фрідеман, як органіст і клавесиніст, переважно в своїх концертах використовував клавесин та піанофорте, як і Йоганн Крістоф Фрідріх. Проте інструментальні уподобання Йоганна Крістіана зосередилися на новому інструменті фортепіано, якій ставав все більш популярним в Англії. Композитори також користувалися різними інструментальними комбінаціями та замінами через те, що в музиці того часу панував експериментальний дух, а така різноманітність давала можливість втілити цікаві творчі ідеї.

\section{СПИСОК ВИКОРИСТАНИХ ДЖЕРЕЛ}

1. Бах К. Ф. Э. Опыт истинного искусства клавирной игры. Санкт-Петербург, 2005. 169 с.

2. Друскин М. С. Клавирная музыка Испании, Англии, Нидерландов, Франции, Италии, Германии XVI XVIII веков. Санкт-Петербург, 2007. 752 с.

3. Захваткин А. Н. Клавирная школа К. Ф. Э. Баха в исторической перспективе: автореф. дис. ... канд. искусствоведения. Нижний Новгород, 2007. 19 с.

4. Любимов А. Исторические инструменты вводят Бетховена в мир романтизма: интервью. URL: https://orpheusradio.ru/news/discussions/1061/lyubimov-istoricheskie-instrumenty (дата звернення 19.09.2020).

5. Любимов А., Мартынова О., Насонов Р. Клавесин и хаммерклавир: друзья-соперники? URL: http://www.earlymusic.ru/uploads/cgmusic/id33/klavesin-hammerklavir.pdf (дата звернення 21.09.2020).

6. Медведик Г. Західноєвропейська клавірна творчість доби пізнього ренесансу - класицизму (питання історії та інтерпретації музичних творів). Актуальні питання гуманітарних наук. Дрогобич, 2017. Вип. 17. С. 86-92.

7. Носина В.Символика музыки И. С. Баха. Москва, 2004. 56 с.

8. Остер Е. В., Быканова М. С. Антропоцентрическая концепция сонатной формы в контексте диалектической триады Гегеля: сравнительный анализ классической и романтической модели. Фортепианное наследие композиторов венской школь:: история, педагогика, интерпретащия. Белгород, 2018. С. 125-129.

9. Ткаченко Е. Клавирные сонаты Ф. Э. Баха: у истоков классического стиля (к вопросу жанровых взаимодействий). Южно-Российский музыкальный альманах. Ростов-на-Дону, 2010. № 2. С. 13-18.

10. Форкель И. Н. О жизни, искусстве и произведениях Иоганна Себастьяна Баха. Москва, 1987, 111 с.

11. The History of the Piano. URL: https://www.piano-keyboard-guide.com/history-of-the-piano.html (дата звернення 20.09.2020).

\section{REFERENCES}

1. Bach K. F. E. Opyt istinnogo iskusstva klavirnoy igry [Experience the true art of clavier playing]. Sankt-Peterburg, 2005. 169 p. [in Russian].

2. Druskin M. S. Klvirnaya muzyka Ispanii, Anglii, Niderlandov, Frantsii, Iyalii, Germsnii XVI - XVIII vekov [Clavier music of Spain, England, Netherlands, France, Italy, Germany of the XVI - XVIII centuries]. Sankt-Peterburg, 2007.752 p. [in Russian].

3. Zahvatkin A. N. Klavirnays shkola K. F. E. Bacha v istoricheskoy perspective [Clavier school of C. F. E. Bach in a historical perspective]: author's abstract scientific paper ... Candidate of History of Music Sciences. Nizhniy Novgorod, 2017. 19 p. [in Russian]. 
4. Lyubimov A. Istoricheskie instrument vvodyat Bethovena v mir romantizma [Historical instruments introduce Beethoven to the world of romanticism]: interview. URL: https://orpheusradio.ru/news/discussions/1061/lyubimov-istoricheskie-instrumenty (дата звернення 19.09.2020). [in Russian].

5. Lyubimov A., Martynova O, Nasonov. Klavesin I hammerklavir: druz'ya-soperniki? [Harpsichord and Hammerklavier: Friends-Competitors?] URL: http://www.earlymusic.ru/uploads/cgmusic/id33/klavesin-hammerklavir.pdf (дата звернення 21.09.2020). [in Russian].

6. Medvedyk G. Zahidnoevropeyska klavirna tvorchist doby piznyogo renesansu - klasytsyzmu (pytannya istorii ta interpretatsii musychnyh tvoriv) [Western European piano music of the late Renaissance - Classicism (questions of history and interpretation of musical works)]. Aktualni pytannya gumanitarnyh nauk. Drogobych, 2017. P. 86-92. [in Ukrainian].

7. Nosina V. Symvolika J. S. Bacha [Symbolism of J. S. Bach's music]. Moskva, 2004. 56 p. [in Russian].

8. Oster E. V., Bykanova M. S. Antropotsentricheskaya kontseptsiya sonatnoy formy v kontekste dialekticheskoy triady Gegelya: sravnitelnyy analiz klassicheskoy I romanticheskoy modeli [Anthropocentric concept of the sonata form in the context of Hegel's dialectical triad: a comparative analysis of the classical and romantic models]. Fortepiannoe naslrdie kompozitorov venskoy shkoly: istoriya, pedagogika, interpretatsiya. Belgorod, 2018. P. 125-129. [in Russian].

9. Tkachenko E. Klavirnye sonaty F. E. Bacha: u istokov klassicheskogo stilya (k voprosu zhanrovyh vzaimodeystviy) [F. E. Bach's Clavier Sonatas: at the Beginning of the Classical Style (on the Question of Genre Interactions)]: musicology work. Yuzhno-Rossiyskiy muzykalnyy almanah. Rostov-na-Donu, 2010. № 2. P. 13-18. [in Russian].

10. Forkel J. N. O zhizni, iskusstve s proizvedeniyah Johanna Sebastiana Bacha [On the life, art and music of Johann Sebastian Bach]. Moskva, 1987, 111 p. [in Russian].

11. The History of the Piano. URL: https://www.piano-keyboard-guide.com/history-of-the-piano.html (дата звернення 20.09.2020). [in English]. 